\title{
Smart-Urea-Controlled-Release-Nitrogen-Fertilizer Menggunakan Plastik Biodegradable Poli Asam Laktat Sebagai Carrier
}

\author{
Mujtahid Kaavessina*, Chitra Husnabilqis, dan Meylani Tri Hardiyanti \\ Program Studi Sarjana Teknik Kimia, Fakultas Teknik, Universitas Sebelas Maret Jl. Ir. Sutami 36A \\ Surakarta, Indonesia \\ E-mail: mkaavessina@gmail.com (Corresponding author)
}

\begin{abstract}
Poly lactic acid is a polymer that has been developed as an alternative to substitution of conventional polymers. The properties of this polymer are biodegradable in nature and non-toxic substances. These polymers potentially can be used as a matrix for urea carries. The aim of this research was to synthesize poly lactic acid in a low molecular weight. This product can be used as a matrix that urea release controller during the process of fertilization. The methodology consisted of two stages. The first stage was polycondensation of lactic acid and degradability test. Lactic acid was mixed with $\mathrm{SnCl} 2$ catalyst $0.1 \%$ and heated to $138 \mathrm{oC}$ for 24 hours. The second stage was producing in the form of Smart Urea Controlled Release Nitrogen Fertilizer (CRNF). Urea was dissolved in poly lactic acid through a heating process at $150^{\circ} \mathrm{C}$ to dissolve urea with variation in urea concentration weight of $0.5 \% ; 0.1 \% ; 0.15 \% ; 0.2 \% ; 0.25 \% ; 0.3 \%$ and CRNF granulation processes. Finally, the mixture was granulated in ambient temperature. Chemical analysis was done the molecular weight of poly lactic acid. The relationship between intrinsic viscosity and molecular weight was used. The IR spectra (FTIR) was used to fine molecular structure. The release testing of urea from the matrix of poly lactic acid uses UV-VIS Spectrophotometer. The results showed that the average molecular weight of poly lactic acid is $1149.49 \mathrm{~g} /$ gmol. FTIR spectra of CRNF with variation in urea concentration weight showed the presence of groups owned by poly lactic acid and urea. The peaks are 1627.03 to $1629.92 \mathrm{~cm}-1$ for the -NH group and 3478.77 to $3498.06 \mathrm{~cm}-1$ for group -OH. The existence of these groups proves the existence of urea in CRNF. The release of urea from poly lactic acid occurs by diffusion. It can be seen, when urea in CRNF form immersed in water, the concentration of urea in water increase as well as the increasing immersed time.
\end{abstract}

Keywords: poly lactic acid, urea, Controlled Release Nitrogen Fertilizer, CRNF, matrix

EQUILIBRIUM Volume 16 No.2 Juli 2017

Online at http:/ / equilibrium.ft.uns.ac.id 


\title{
1. Pendahuluan
}

Penggunaan pupuk anorganik dapat meningkatkan kandungan unsur hara dalam tanah, mempercepat pertumbuhan tanaman pangan (khususnya padi), dan meningkatkan hasil produksi pertanian. Pupuk anorganik adalah pupuk hasil proses rekayasa secara kimia, fisik dan atau biologis yang dibuat dari berbagai bahan kimia sehingga memiliki persentase kandungan hara yang tinggi. Salah satu metode pemberian pupuk adalah dengan menebarkannya ke tanah di sekitar akar tanaman, jenis pupuk ini disebut pupuk akar (contoh: urea, NPK, dan dolomit). Salah satu inovasi dalam metode pemberian pupuk jenis ini adalah dengan merekayasa pupuk tersebut menjadi Slow Release Fertilizer (SRF).

Salah satu bentuk pupuk SRF adalah Controlled Release Nitrogen Fertilizer (CRNF). CRNF) merupakan jenis pupuk dengan mekanisme pelepasan unsur hara berupa nitrogen secara perlahan dan berkala mendekati pola penyerapan oleh tanaman sehingga unsur hara yang terkandung dalam pupuk tidak terbawa oleh air dan tepat sasaran. Pengembangan pupuk ini secara umum dilakukan dengan melindungi kandungan unsurnya baik secara kimiawi maupun mekanis. Perlindungan kimiawi dengan cara mencampur urea dengan zat kimia, sehingga pupuk tersebut lepas secara terkendali. Sedangkan perlindungan secara mekanis dengan membungkus pupuk dalam bentuk granule dengan bahan pembungkus yang bersifat semipermeabel (Nick C., 2004).

Nitrogen merupakan unsur hara esensial bagi tanaman. Nitrogen berguna untuk mempercepat pertumbuhan tanaman dan merupakan penyusun utama protein yang diperlukan oleh tumbuhan maupun hewan dalam jumlah besar (Nasoetion, 1996). Urea merupakan pupuk yang memiliki kadar $\mathrm{N}$ yang tinggi $(46 \%)$, mudah larut dalam air, dan higroskopis sehingga penyimpanannya harus di tempat yang kering dan tertutup rapat. Karena tingginya kadar nitrogen dan sifatnya yang mudah larut dalam air, pupuk urea ini sangat cocok apabila dijadikan pupuk dalam bentuk CRNF.

Hasil studi literatur menyatakan bahwa belum ada yang menggunakan plastik biodegradable poli asam laktat sebagai matriks CRNF. Kebanyakan penelitian sebelumnya menggunakan zeolit sebagai matriksnya. Namun zeolit tersebut mengandung unsur Al yang apabila pemakaiannya dilakukan secara berlebih akan merusak tanaman. Hal tersebut memberikan ide inovasi untuk menggunakan plastik poli asam laktat berberat molekul rendah sebagai matriks pembawa pupuk urea dalam bentuk CRNF karena biodegradasi plastik poli asam laktat oleh mikroba menghasilkan biomassa dan gas-gas yang tidak beracun bagi tanaman (Noezar dkk, 2008).

Pengembangan CRNF dengan menggunakan plastik biodegradable poli asam laktat sebagai matriksnya menjadi topik yang sangat menarik untuk diteliti, karena Smart-UreaControlled-Release-NitrogenFertilizer dibuat dengan melarutkan urea dalam poli asam laktat dengan komposisi tertentu. Pelepasan urea di dalam matriks dapat ditentukan dengan mengatur kecepatan degradasi dari plastik biodegradable poli asam laktat. Urea akan keluar lambat seiring terurainya plastik poli asam laktat saat dilakukan pemupukan.

Penelitian ini dilakukan untuk mensintesis plastik poli asam laktat berberat molekul rendah, membuat Smart-Urea-Controlled-ReleaseNitrogen-Fertilizer dengan matriks plastik biodegradable poli asam laktat, serta mengetahui pelepasan pupuk urea dalam bentuk CRNF.

\section{Metode Penelitian}

\begin{abstract}
Alat dan Bahan
Bahan yang digunakan adalah asam laktat, $\mathrm{SnCl} 2.2 \mathrm{H} 2 \mathrm{O}$, urea, kloroform, dan akuades. Rangkaian alat polimerisasi asam laktat ditunjukan pada Gambar 1 dan rangkaian alat blending ditunjukkan pada Gambar 2.
\end{abstract}

\section{Cara Penelitian}

Penelitian di Laboratrium Operasi Teknik Kimia, Program Studi Sarjana Teknik Kimia, Universitas Sebelas Maret, Surakarta, dibagi menjadi dua tahap, yaitu tahap polimerisasi asam laktat dan pembuatan pupuk urea dalam bentuk CRNF. 


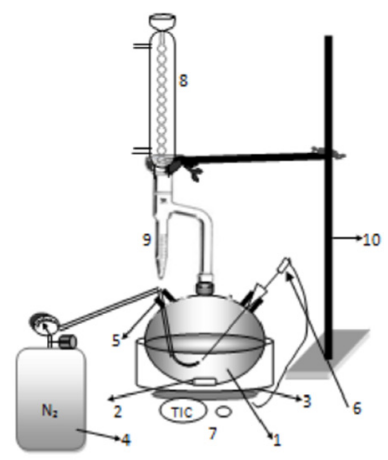

Keterangan :

1. Reaktor polimerisasi

2. Pengaduk

3. Oil bath

4. Tabung $\mathrm{N}_{2}$

5. $\mathrm{N}$ inlet

6. Termokopel

7. Heat magnetic stirer

8. Condensor

9. Dean stark

10 Statif dan klem

condenser

Gambar 1. Rangkaian Alat Polimerisasi

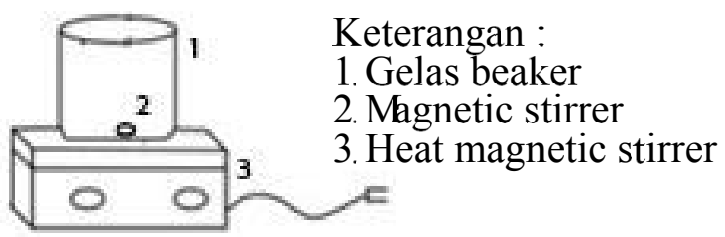

Gambar 2. Rangkaian Alat Blending

\section{Tahap I. Polimerisasi Asam Laktat}

Dalam tahap ini ditetapkan variabel tetap adalah konsentrasi larutan asam laktat, berat katalis, dan waktu polimerisasi. Tahap polimerisasi asam laktat adalah sebagai berikut:

a. $\quad 400 \mathrm{~g}$ asam laktat dimasukkan ke dalam labu leher tiga.

b. Katalis $\mathrm{SnCl} 2$ dengan kadar $0,1 \%$ berat terhadap berat asam laktat dimasukkan ke dalam labu leher tiga.

c. Larutan tersebut dipanaskan hingga $138 \mathrm{oC}$ dan dijaga konstan selama 24 jam.

\section{Tahap II. Pembuatan Pupuk Urea Dalam Bentuk CRNF}

Tahap pembuatan pupuk CRNF terdiri dari: blending, dan proses granulasi.

a. Dalam proses blending, urea dilarutkan dalam poli asam laktat melalui proses pemanasan pada suhu 150 oC sampai urea laru dengan variasi kadar urea $0,5 \% ; 0,1 \% ; 0,15 \% ; 0,2 \% ; 0,25 \% ; 0,3 \%$ berat.

b. Proses granulasi dilakukan untuk mendapatkan pupuk CRNF dalam bentuk granule.

\section{Analisis Kimia}

a. Berat molekul poli asam laktat dengan menggunakan hubungan viskositas intrinsik dan berat molekul

1. Sampel diambil setelah waktu polimerisasi 24 jam.

2. Viskositas instrinsik diukur mengunakan viskometer Ostwald didasarkan pada persamaan Solomon-Cuita.

b. Karakterisasi FTIR

Poli asam laktat dan urea sebagai control, hasilnya untuk membandingkan dengan pupuk urea CRNF. Uji FTIR dilakukan di Laboratorium Terpadu, FMIPA, Universitas Sebelas Maret, Surakarta menggunakan alat Fourier Transform Infra Red Shimadzu Prestige-21.

c. Uji kadar urea dalam larutan menggunakan Spectrofotometer UV-VIS yang dilakukan diLaboratrium Proses, Program Studi Sarjana Teknik Kimia, Universitas Sebelas Maret, Surakarta. Pengujian pelepasan pupuk urea dari matrik poli asam laktat dilakukan secara invitro.

1. Pupuk urea CNRF dilakukan uji pelepasan dari matriks dengan dissolution tester menggunakan medium air sebanyak $50 \mathrm{ml}$.

2. Tiap periode waktu tertentu $(8,16,24,32,40,48$ jam) dilakukan pengambilan sampel sebanyak $3 \mathrm{ml}$. 
3. Sampel kemudian dianalisis dengan menggunakan Spectrofotometer UV-VIS

\section{Hasil dan Pembahasan}
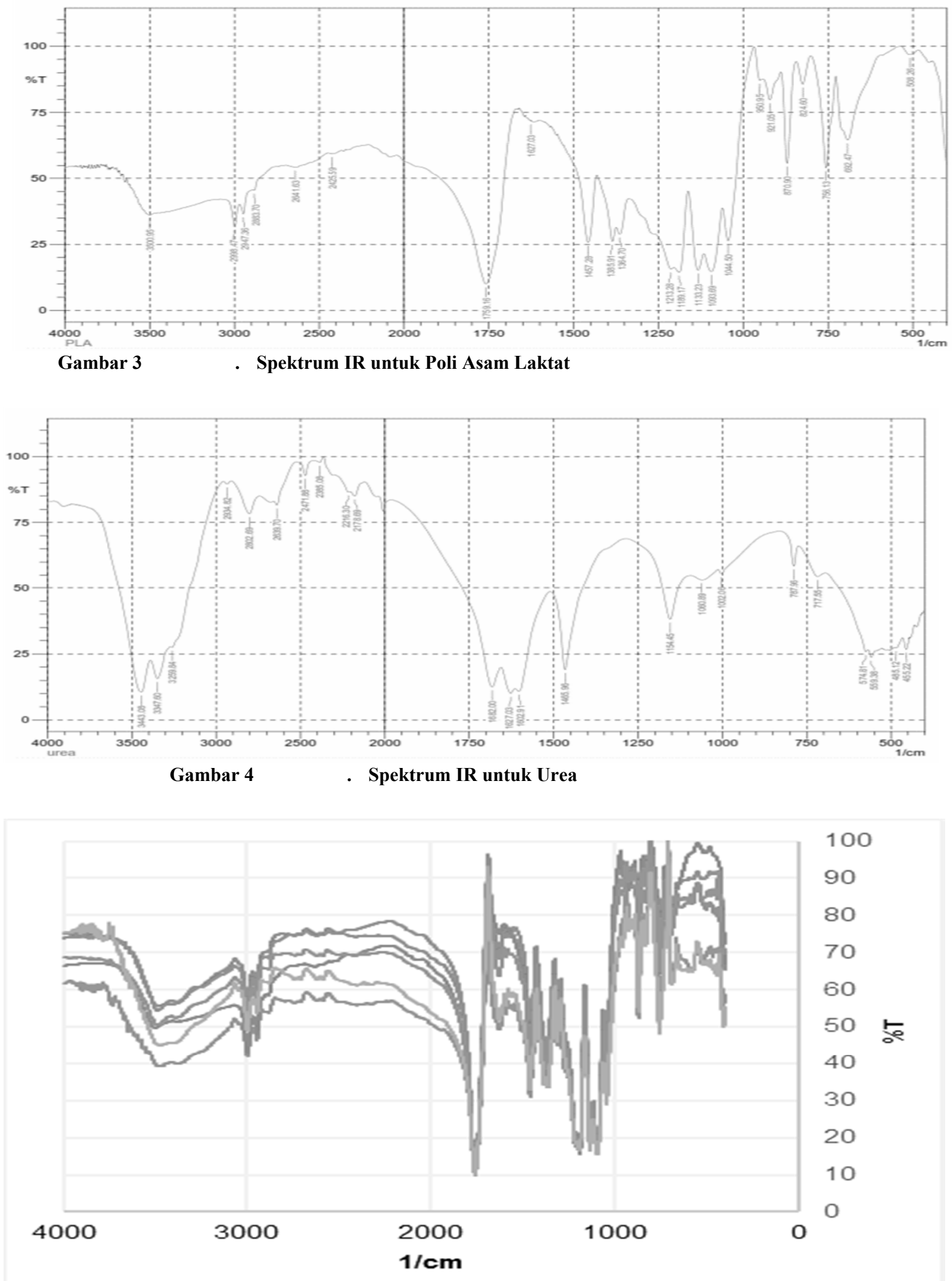

Gambar 5

. Spektrum IR untuk CRNF Berbagai

Variasi Berat Urea 


\section{Pembuatan Smart-Urea-CNRF}

Pembuatan Smart-Urea-CNRF dilakukan dengan dua tahap yaitu tahap polimerisasi asam laktat dan tahap pembuatan pupuk urea dalam bentuk CRNF. Dalam tahap polimerisasi asam laktat, dilakukan proses polimerisasi polikondensasi langsung untuk membentuk poli asam laktat yang digunakan sebagai matriks pupuk urea, sedangkan tahap berikutnya adalah blending antara matriks tersebut dengan urea untuk membentuk CRNF. Untuk selanjutnya, sampel yang berbentuk granule dilakukan karakterisasi.

\section{Analisis Berat Molekul Poli Asam Laktat}

Analisa berat molekul dilakukan melalui pengukuran viskositas intrinsik, proses polimerisasi asam laktat yang terjadi pada suhu $138 \mathrm{oC}$ selama 24 jam dengan katalis $\mathrm{SnCl} 2.2 \mathrm{H} 2 \mathrm{O}$ sebesar $0,1 \%$ berat didapatkan berat molekul poli asam laktat sebesar 1149,49 g/gmol.

\section{Karakterisasi Smart-Urea-CRNF}

Analisis spektroskopi FTIR berguna untuk mengetahui ciri struktural senyawa kimia pada sampel dan mendeteksi perubahan gugus fungsi akibat reaksi kimia. Hasil analisis FTIR dari poli asam laktat ditunjukkan pada Gambar 3. Interpretasi dari gambar tersebut adalah pada peak 1759,16 cm-1 untuk gugus -COO-, peak 1093,69cm-1 untuk gugus -O-, peak 2947,36 cm-1 dan 2998,47 cm-1 untuk gugus $\mathrm{CH} 2$ - dan-CH3, peak 3500,95 cm-1 untuk gugus $-\mathrm{OH}$, dan pada peak 1759,16 cm-1 untuk gugus $-\mathrm{C}=\mathrm{O}$. Hasil interpretasi gugus-gugus sesuai dengan gugus yang dimiliki poli asam laktat. Dari hasil FTIR urea yang ditunjukan pada Gambar 4, didapatkan intepretasi pada peak 1060,89 cm-1 dan 1154,45 cm-1 untuk gugus $-\mathrm{CN}$, peak 1627,03 cm-1 untuk gugus $-\mathrm{NH}$, dan peak 3259,84 cm-1, 3347,60 cm-1, dan 3443,08 cm-1 untuk gugus $-\mathrm{OH}$.

Hasil analisa FTIR CRNF dengan berbagai variasi berat urea menunjukan adanya gugusgugus yang dimiliki oleh poli asam laktat dan urea. Gambar 5 menunjukan bahwa analisis FTIR CRNF yaitu pada peak 1627,03-1629,92 cm-1 untuk gugus -NH dan peak 3478,77-3498,06 cm-1 untuk gugus -OH. Adanya gugus-gugus tersebut membuktikan adanya urea dalam CRNF.

\section{Hasil Percobaan Release Urea}

Pelepasan urea dari matriks poli asam laktat ke dalam air dengan rentang waktu 8, 16, 24, 32 dan 48 jam dapat dilihat pada Gambar 6.

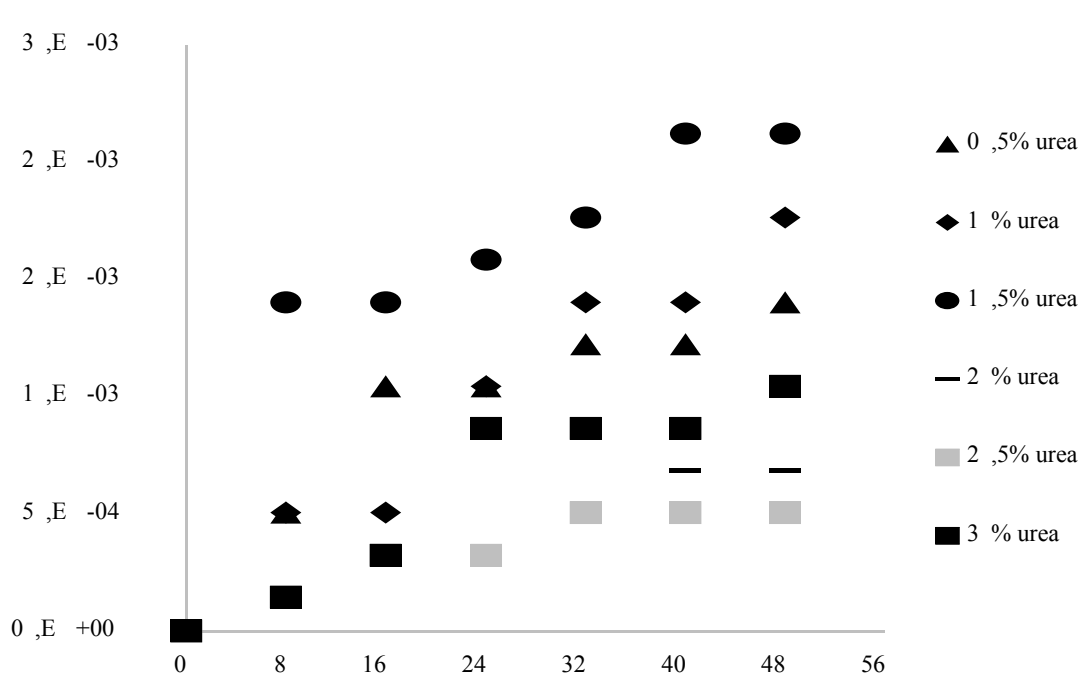

\section{Gambar 6. Grafik Hubungan antara Konsentrasi Urea $(\mathrm{g} / \mathrm{mL})$ dengan Waktu (jam)}

Dari gambar 6 dapat dilihat bahwa konsentrasi urea yang release pada air paling banyak ditunjukkan pada persentase berat urea 1,5\%. Konsentrasi urea yang release pada air paling sedikit ditunjukkan pada persentase berat urea 2,5\%. Pengaruh persentase berat urea dalam CRNF terhadap konsentrasi urea yang release tidak dapat terlihat trend-nya. Hal ini memungkinkan untuk dilakukan penelitian selanjutnya. Namun, konsentrasi urea yang release dalam air terhadap waktu semakin tinggi.

Smart-Urea-Controlled-Release-Nitrogen-Fertilizer Menggunakan Plastik Biodegradable Poli Asam Laktat Sebagai Carrier (Mujtahid Kaavessina, Chitra Husnabilqis, dan Meylani Tri Hardiyanti) 


\section{Kesimpulan}

Dari penelitian ini dapat diambil kesimpulan sebagai berikut :

1. Proses polimerisasi asam laktat menjadi poli asam laktat sebagai matriks CRNF dilakukan dengan proses polikondensasi langsung selama 24 jam yang menghasilkan berat molekul poli asam laktat sebesar 1149,49 g/gmol.

2. Pembuatan pupuk urea dalam bentuk CRNF adalah dengan cara mencampurkan pupuk urea dengan poli asam laktat yang telah dicairkan dengan pemanasan terlebih dahulu.

3. Pelepasan pupuk urea dari matriks poli asam laktat terjadi karena terdegradasinya matriks poli asam laktat. Hal ini dibuktikan, ketika dibenamkan di dalam air, dengan semakin bertambahnya waktu, kadar pupuk urea dalam air semakin bertambah.

\section{Daftar Pustaka}

Hoeung, P., Bindar, Y., Senda, S.P. 2011.

Development of Granular Urea-Zeolite Slow Release Fertilizer Using Inclined Pan Granulator,. Jurnal Teknik Kimia Indonesia. 2(10): 102-111

Hwang, J. K., S. P. Hong, dan C. T. Kim. 1997. Effect of Molecular Weight and $\mathrm{NaCl}$ Concentration on Dilute Solution Properties of Chitosan. J Food Sci Nutr. 2:1-5

Hyon, S.H., Jamshidi, K., Ikada, Y., 1997. Synthesis of Polylactides with Different Molecular Weights. Biomaterials. 18(22):1503-8.

Jung, S., P. Wang, Y. M. Zhang, and X. J. Mi, J. 2006. Rapid Melt Polycondensation of LLacticAcid under Microwave Irradiation.

Macromolecular Research. 14(6): 659-662

Nasoetion, A.H., 1996. Pengantar ke Ilmu-Ilmu Pertanian. Pustaka Literatur Antar Nusa.

Nick, C. 2004. Fertilization: Fundamentals of Turfgrass Management. John Wiley \& Sons. pp. 137-138, 142-143

Noezar, I., Praptowidodo, V, S., Nugraheni, R., Nasution, M.H. 2008. Biodegradable Polimer dari Asam Laktat. Jurnal Teknik Kimia Indonesia. 6(2): 626-633 Pupuk Sriwidjaya. 2016. Urea Tentang Urea. (http://www.pusri.co.id/ina/urea-tentangurea/diunduh tanggal 10 Maret 2016 pukul $20.29 \mathrm{WIB})$

Swift, G. 1993. Directions for Environmentally Biodegradable Polymer Research.Acc.

Chem. Res. 26 (3) : 105 